\title{
Nova política editorial
}

\author{
New editorial policy
}

\section{J. Vasconcelos-Raposo}

Director da Revista Motricidade - Universidade de Trás-os-Montes e Alto Douro

Este é o tipo de editorial que nenhum director de revista, que preze a ciência na sua forma mais pura, gosta de escrever. Mas, infelizmente, apesar das resistências que ao longo dos últimos tempos temos vindo a colocar-lhe, a realidade que nos é imposta nos tempos que correm obriga-nos à implementação de uma política de partilha de custos.

Inevitavelmente, apelamos aos nossos colaboradores para partilharem as despesas inerentes à produção da revista, uma vez que os custos actuais, tanto a nível financeiro como académico, profissional e pessoal, relativamente aos membros da equipa, assumem patamares não aceitáveis, para quem tenha por princípio gerir recursos humanos de forma justa, e fundamentalmente sem prejudicar quem com eles colabora. A verdade é que a equipa editorial da Motricidade sacrifica o seu tempo, retirando tempo à sua produtividade científica e, infelizmente, também às suas famílias, porque as suas obrigações profissionais, forçosamente, têm de ser mantidas.

Para que os nossos colaboradores possam compreender a decisão agora tomada, importa esclarecer alguns aspectos. Dos vários a considerar, talvez o mais relevante é que todos os membros da equipa editorial prestam um serviço absolutamente gratuito, apesar do vasto tempo que usam no tratamento editorial dos artigos que nos chegam.

É com particular agrado que registamos o facto de sermos a Revista Portuguesa que integra a Scielo que mais atempadamente disponibiliza os seus materiais. É, ainda, motivo de satisfação, para a equipa editorial, a constatação de que os materiais por nós produzidos e publicados foram descarregados, no processo de "open access", mais de 300 mil vezes. O número de artigos submetidos tem crescido de forma contínua, assim como verificamos uma melhoria na qualidade dos materiais que nos são confiados. A inclusão da Motricidade em novas bases de indexação é, também, uma manifestação clara do nosso crescimento e consolidação na comunidade científica. Os artigos que publicamos atraem estudiosos em mais de vinte países, demonstrando que algumas das ferramentas actualmente disponibilizadas na internet, como por exemplo os programas de tradução, tornam possível que os nossos materiais sejam lidos em línguas tão díspares como Russo, Árabe, Chinês, Inglês, Espanhol, entre outras.

Mas tudo isso implica uma sobrecarga de trabalho para a equipa editorial que neste momento assume contornos em que o sacrifício pessoal corre o risco de ultrapassar a satisfação altruística que tem tipificado, ao longo destes doze meses, a entrega de todos ao projecto Motricidade. Recordamos que todo o trabalho editorial é realizado de forma gratuita, à excepção da impressão e que esta componente representa um encargo efectivo que atinge valores dificilmente suportáveis para a estrutura actual.

Enquanto revista científica, somos uma peça importante na vida académica daqueles que nos escolhem como veículo para consolidarem os requisitos de que necessitam para progredir académica e profissionalmente, assim como para todos aqueles que por critério dos programas de mestrado, têm de publicar os seus resultados numa revista credível, tal como 
o confirma os sistemas de qualificação, de que é exemplo o Qualis.

Para poderem entender a política que agora implementamos, julgo que devemos esclarecer os nossos colaboradores sobre o volume de trabalho que está envolvido na preparação e publicação dos seus trabalhos. Passo a descrever.

Sempre que submetem um artigo o director da revista divide a tarefa de rever os textos com mais um dos editores-chefe e de imediato estes dão feedback aos autores sobre a primeira avaliação. A maioria dos casos requer revisões a vários níveis $\mathrm{e}$, em circunstâncias normais, num período nunca superior a quinze dias são comunicadas ao autor identificado para esse efeito. É feita uma segunda submissão, pelos autores, o que implica uma nova leitura por parte dos primeiros avaliadores.

Quando aceites as alterações, segue-se o processo de encaminhamento para os membros da equipa editorial responsáveis pela gestão da identificação e encaminhamento do texto para pelo menos dois revisores. O processo tem continuidade na avaliação por pares (que também realizam as suas tarefas de forma gratuita). Há o retorno dos avaliadores na forma de pareceres que, por sua vez, são apreciados pelo director e encaminhados para os autores de forma a poderem acomodar as eventuais alterações sugeridas. Feitas as alterações os autores re-submetem, essa segunda submissão é revista pelos editores, dada a conhecer aos avaliadores, que emitem um segundo parecer que é apreciado pelo director que então decide sobre a publicação ou não do artigo.

Tomada esta decisão, o artigo é encaminhado para a edição final. Uma vez elaborada a $1^{\mathrm{a}}$ versão do artigo a ser publicado, é enviada uma cópia aos autores para procederem à última revisão do texto antes do mesmo ser encaminhado para os serviços gráficos. Neste processo calculamos que cada artigo envolva no mínimo cerca de 8 a 10 horas de trabalho.
Após esta preparação seguem-se os custos de preparação para a impressão dos números em formato de papel e a preparação para a edição digital e o respectivo encaminhamento para as diferentes bases de indexação.

Se tivermos em conta a classificação académica das pessoas em causa, estamos certos que os nossos colaboradores facilmente entenderão que os valores que agora a Motricidade solicita continuarão a ser insuficientes para cobrir os custos inerentes à produção editorial de cada um dos seus números. Por essa mesma razão é que designamos a nossa política como "partilha de custos". Gostaríamos de alargar o número de artigos a publicar por número, e assim melhor acomodar o crescente volume de submissões e, também, valorizar a qualidade dos artigos que nos são confiados, mas acontece que o custos inerentes a tal prática tornam o objectivo dificilmente atingível a curto prazo, caso não sejamos acompanhados neste esforço pelos nossos colaboradores.

Assim, para os artigos submetidos até Maio de 2010 solicitaremos um contributo na forma voluntária, mas para todos os que nos chegaram após esta data a publicação dos manuscritos passa pela aceitação das seguintes condições e montantes: artigos com até três autores, 100 euros; artigos com quatro e mais autores, 40 euros por autor.

Estão isentos de qualquer tipo de colaboração financeira todos os colaboradores doutores que participem na vida da revista, na forma de revisores e que tenham a prática regular de retorno no prazo máximo de trinta dias. Sempre que o nome deste tipo de colaborador aparece num artigo a ser publicado por nós, o montante relativo à sua parte será deduzido dos custos.

Importa esclarecer que os contributos só são aplicáveis quando o manuscrito é aceite para publicação.

Por último, deixamos em aberto o convite a todos os que desejem ser revisores da revista que nos façam sentir tal vontade, enviando-nos um breve curriculum vitae, que nos permita 
avaliar a experiência acumulada como pesquisadores e, consequentemente, no processo de submissão e preparação de artigos científicos.
Antecipadamente, certo da compreensão e da adesão de todos ao Projecto Motricidade, o nosso agradecimento. 